\title{
To Talk or Not to Talk: Silence, Torture, and Politics in the Portuguese Dictatorship of Estado Novo
}

\author{
Miguel Cardina
}

\begin{abstract}
This article is based on the author's wider research into Maoism in Portugal from 1964 to 1974 during the final years of the Estado Novo (New State) dictatorship. It analyzes the so-called "issue of conduct," that is, the "correct" behavior of militants under arrest and torture. The aim is to reveal how this subject-heavily defined by the dualism of "talking" / "not talking" - has endured in time and to emphasize how, through this dualism, connections can be established between torture, silence, and memory.
\end{abstract}

Keywords: dictatorship, Estado Novo, memory, Portugal, silence, torture

During the twentieth century, Portugal lived through the longest dictatorship in Western Europe. Established at the beginning of the 1930s during the rise of fascism, the Estado Novo (New State) was toppled on April 25, 1974, by a military coup led by young captains weary of a colonial war that had begun in Africa in 1961 and for which there seemed no end in sight. The "Carnation Revolution," as it was called, led to an intensely revolutionary period, extending from April 1974 to November 1975, which saw the emergence of political and social actors whose practices and discourse were markedly left wing, despite

The author would like to thank Rui Bebiano, Paula Godinho, António Monteiro Cardoso, José Manuel Lopes Cordeiro, and Fernando Rosas for the valuable discussions held with them; Luís Trindade for the opportunity to spend some months at Birkbeck College, University of London, where part of this work was written; and the Portuguese Foundation for Science and Technology for its financial support (SFRH/SPD/72447/2010). He would also like to thank Kathryn Nasstrom, editor of the Oral History Review, for her meticulous and encouraging supervision and the blind reviewers for their opportune recommendations and suggestions. An initial version of this article was presented at the XVII International Oral History Conference held in Buenos Aires, Argentina, September 3-7, 2012. 
the rifts between them. During this period, the memory of antifascism clearly dominated public discourse and was frequently used as a form of political legitimation. However, this did not mean that memories of the repression exercised by the dictatorship were publicly exorcised. A description of two episodes that took place after April 25, 1974, may help to make this clear.

The first episode occurred in 1976, when the recently created Partido Comunista Português (Reconstruído) (Portuguese Communist Party (Reconstructed) - PCP (R)), decided to carry out a self-styled "Proletarianization and Revolutionization Campaign." 1 In Maoist terms, the campaign aimed to reeducate militants through direct, ongoing contact with "the masses," such as encouraging their implantation in working class and rural areas. Another aspect of the campaign involved detailed investigations of the reasons for detention and of militants' behavior while under torture and in prison during the dictatorship. One hundred fifty cases were analyzed. At the time it was concluded that roughly half of the militants were imprisoned for "reasons that were not political, or were political but had no consequences in terms of assessing conduct." However, thirty-four cases of "bad conduct" were detected and dealt with in different ways: Some activists were reintegrated as militants, some were demoted to sympathizers, while others were expelled from the party. ${ }^{2}$

The second "episode" has no fixed date or clearly defined actors, but alludes instead to the relationship between history, archive, and past experience. After the fall of the dictatorship, a committee was created to abolish the PIDE/DGS (Polícia Internacional de Defesa do Estado / Direcção-Geral de Segurança-International State Defence Police/Directorate-General for Security), the state police force of the Estado Novo. It was charged with fighting "crimes against the security of the state," for which it resorted to torture and even, at times, assassinations. ${ }^{3}$ This abolition committee had a troubled

\footnotetext{
1 The most visible face of the PCP (R) was its mass front, the União Democrática Popular (People's Democratic Union - UDP), from which one MP was elected to the Constituent Assembly in 1975.

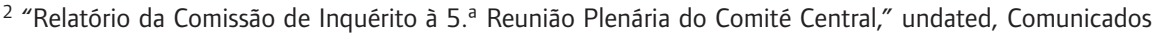
e Panfletos, CMLP (depois de 1975), Archives of the Centro de Documentação 25 de Abril, University of Coimbra, Coimbra, Portugal.

${ }^{3}$ The PIDE was created in 1945 to replace the Polícia de Vigilância e Defesa do Estado, PVDE (State Surveillance and Defence Police) formed in 1933. In 1969, after António de Oliveira Salazar was replaced by Marcelo Caetano, the PIDE changed its name to DGS but essentially retained the same powers and methods. It was abolished in 1974, after the fall of the regime. See Irene Flunser Pimentel, A história da PIDE (Lisbon: Círculo de Leitores, 2007). Sleep deprivation, "statue" torture, beatings, insults, and blackmail were the most common forms of torture used by the PIDE/DGS, and their applications were developed over time. Initially, beatings were very common, but from the 1950s onward, methods that left no visible marks became more widely used, in particular sleep torture (even though beatings still continued). The intensity of the torture also tended to vary according to social class (and was more severe for workers and peasants, particularly if they were members of the Communist Party). In addition, torture could be medically assisted to increase the suffering of prisoners without putting their lives at risk. Afonso Albuquerque has recorded the results of a sample of fifty exprisoners interviewed between 1974 and 1975 by the Grupo de Estudo da Tortura (Torture
} 
existence, suffering from internal political rifts and the lack of a legal framework for trials involving the "pides" (as they were commonly termed). Since one of the main tasks of the committee was to gather evidence in order to instigate legal proceedings against members of this particular police force and its collaborators, it had access to sensitive information about the repressive apparatus and the resistance organizations and militants who had been imprisoned or kept under surveillance. This was sufficient grounds for rumors to emerge about documents going missing at the hands of the political powers, rumors that even today have not completely subsided.

What is certain is that some former militants, in the tumultuous revolutionary context, had access to PIDE/DGS documents and kept those that referred to them, possibly due to fear of what they might have contained or in the belief that an individual's past is strictly his/her own business. This latter notion becomes especially pertinent when referring to the repressive apparatus. Issues such as the kind of ownership that individuals who had been persecuted or kept under surveillance should have over their own documents or documents that refer to them, and especially how far these documents should be "expunged" if accessible to third parties, such as researchers, would feature in the debates that preceded the opening up of the PIDE/DGS archives to the public. In 1996, the return to their owners of letters, photographs, and other personal documents seized by the PIDE/DGS was even the subject of a parliamentary debate, with some former prisoners favoring this solution. The prevailing decision, however, was that no documents should be returned, and the archive is nowadays open for consultation, subject to certain restrictions.

These two phenomena-the PCP $(R)$ investigation and the complicated relationship between memory, history, and the PIDE/DGS archive-clearly show how the past is not simply a shadow from which we are gradually retreating; rather, it is a phantom lingering on in time. In the specific case of post-revolutionary Portugal, although the political and social situation changed after April 25,1974 , painful experiences of torture did not fade away significantly following the change of regime. The revolution evoked memories of antifascism (one

\footnotetext{
Study Group). In interrogations, sleep deprivation was used in 96 percent of cases. According to the same study, this was followed by beatings (46 percent), "statue" torture (38 percent), insults and blackmail (30 percent), changes in temperature ( 8 percent), recordings played on loudspeakers ( 8 percent), and electric shocks administered with a cattle prod (4 percent). During the colonial wars in Africa, the torture applied to members of the liberation movements and their sympathizers was much more violent. Afonso Albuquerque, Stress - Causas, prevenção e controlo - um guia prático (Lisbon: Informação e Saúde, Texto Editora, 1987). On the PIDE/DGS during the colonial war, see Dalila Cabrita Mateus, A PIDE/DGS na guerra colonial (Lisbon: Terramar, 2004). According to Irene Pimentel, PIDE/DGS had 2126 employees and approximately 20,000 informers; it opened 6215 cases and 1089 were brought to trial. In the context of the revolution, the great majority received sentences of no more than six months in prison. In Portugal, "transitional justice" was "low intensity," involving light and selective sentences. Irene Flunser Pimentel, "A polícia política do Estado Novo português - PIDE/DGS: História, justiça e memória," Acervo 24, no.1 (2011): 151.
} 
of the first acts associated with transforming the military coup into a revolution was the popular occupation of the PIDE/DGS headquarters), but the urgency of those "fevered times" left little space for a cathartic approach to individual suffering.

\section{The "Issue of Conduct"}

It is also necessary to consider how the parties on the left, namely the Partido Comunista Português (Portuguese Communist Party - PCP) and various Maoist groups, dealt with the so-called "issue of conduct," that is, the behavior of militants subjected to torture. The model that was adopted was associated with principles defined by the PCP. It was inspired by the attitude of a former prisoner, Francisco Miguel, when subjected to torture in December 1939 and was codified, in 1947, in a document entitled Se fores preso, camarada (If you are taken prisoner, comrade). ${ }^{4}$ Prior to this, the recommended behavior consisted of trying to deceive the police by evading facts or concealing responsibilities, a method that would not prove very effective. Se fores preso, camarada instead defined a set of procedures to be followed by prisoners, including the rule that militants should never make any kind of statement to the police. ${ }^{5}$

When the model was appropriated by the Maoists, certain discursive variations were introduced. ${ }^{6}$ The PCP was criticized for approaching the question from the point of view of honor and loyalty and for using religious concepts such as hell, paradise, and purgatory. "Good conduct," therefore, emerged as the result of following the correct and appropriate political line. In 1973, after some cases of informers among the rank and file, the Comités Comunistas

\footnotetext{
${ }^{4}$ The document went through several print runs between 1947 and 1974 and was successively revised. See José Pacheco Pereira, Álvaro Cunhal. Uma biografia política. Vol. 2 - «Duarte», o dirigente clandestino (Lisbon: Temas e Debates, 2001), 682-708.

${ }^{5}$ See José Pacheco Pereira, Álvaro Cunhal, Uma biografia política, Vol. 1 - Daniel, o jovem revolucionário (Sacavém: Temas e Debates, 1999), 385-92. Not all of the communist or clandestine movements adopted similar rules. The idea of the revolutionary as unbreakable and of informing as the supreme weakness does, however, appear in various contexts. On the "ethics of sacrifice" and the particularly violent Argentinean case, see Ana Longoni, Traicones. La figura del traidor en los relatos acerca de los sobrevivientes de la représión (Buenos Aires: Grupo Norma, 2007).

${ }^{6}$ The designation "Maoist" is used here to cover all groups inspired by Chinese positions. However, it is possible to distinguish two political camps that differed in specific ways. The first was formed as a result of the Sino-Soviet split, leading to the formation of small collectives aligned to the Chinese critique of the USSR in the first half of the 1960s. These groups defined themselves as "Marxist-Leninists." A second, more resolutely "Maoist" wave emerged at the end of the 1970s, influenced by the Chinese Cultural Revolution and converging with the youthful radicalism of the time. Robert Alexander's two books provide perhaps the most comprehensive portrait of international Maoism in the 1960s and 1970s, although they contain many omissions and several errors. See Robert J. Alexander, International Maoism in the Developing World (Westport, CT: Praeger, 1999); Robert J. Alexander, Maoism in the Developed World (Westport, CT: Praeger, 2001). For an analysis that focuses on Portugal, see Miguel Cardina, Margem de certa maneira. O maoismo em Portugal: 1964-1974 (Lisbon: Tinta-da-China, 2011).
} 
Revolucionários (marxistas-leninistas), (Revolutionary Communist Committees (Marxist-Leninist) - CCR(m-I)) considered that "in the apparent isolation of the torture chamber" neither prisoner nor torturer was alone but was accompanied by the class whose interests they represented. ${ }^{7}$ In more inflexible language, the Movimento Reorganizativo do Partido do Proletariado (Movement for the Reorganization of the Party of the Proletariat - MRPP) stated that "treason ... will never be the result of violent torture, physical weakness or illness." It would instead be the result of "a decadent ideology, class nature and social practice that has nothing to do with the proletariat and the people." ${ }^{8}$ From 1970 onwards in particular, some organizations even encouraged a more hostile stance in inquisitorial contexts, with some prisoners attacking PIDE/DGS agents during interrogations.

As a rule, the Maoist groups made a theoretical distinction between active collaboration with the police (betrayal) and the inability to resist torture under intense physical and psychological pressure (breakdown). A breakdown could lead to informing or simply to confirming information produced by the police, but the extent of the concessions made was not always easy to determine. It very often depended on information passed on to the outside by prisoners or what the groups were able to deduce from the level of subsequent persecution to which they were subjected. Making statements, especially if they incriminated other militants, was widely repudiated, with some groups supporting the immediate expulsion of any member who "talked.." The rule of never making a statement would signify revolutionary strength and was the only truly efficient means of defending the organization.

Within this context, interpretations of the subject of conduct were greatly influenced by signs of heroism or weakness. Since they had strong moral connotations, these interpretations did not vanish with the downfall of the dictatorship. In the post-April 25 period, the issue re-emerged in various forms, almost always in restricted circles and often serving as a weapon to attack adversaries. "Exemplary attitude" emerged as a superior quality that made the revolutionary capable of subordinating the body to ideals. Weakness was viewed more

\footnotetext{
7 “Comunicado sobre as prisões de Agosto-Setembro de 1972," February. 1973, Comunicados e Panfletos, CCR (m-I), Archives of the Centro de Documentação 25 de Abril. Created in 1970, the CCR (m-I) was active in certain Lisbon student circles and working class districts on the outskirts of Lisbon; it was heavily targeted by the PIDE/DGS between 1972 and 1973.

8 "Fogo sobre os traidores-Agentes da burguesia infiltrados no seio da revolução!" Luta popular, November 14, 1973. Founded in September 1970, the MRPP would become known for its fervent anticolonial activism, triumphalist language, and incisive critique of all other leftist movements.

${ }^{9}$ In opposition to this, O Bolchevista (The Bolchevist) argued that considering "bad attitude to be total destruction and the impossibility of reconstructing oneself as a revolutionary means accepting a passive, metaphysical attitude." "Contra as tendências oportunistas," O Bolchevista, no. 1, March 1970. For this reason, it was criticized by other Marxist-Leninist organizations and later issued a self-critique of its position. See “O CML de P e a atitude na polícia," O Bolchevista, no. 7, November/December 1971.
} 
ambiguously, used as a means of ostracism, contextualized within the circumstances in which individuals "talked" and the consequences of having "talked," or served as a justification for placing militants in front organizations. ${ }^{10}$

\section{The "Issue of Conduct" in Memory: Torture, Silence, and Political Subjectivity}

Understanding the matter of "talking or not talking" in the face of torture and police violence means also understanding how the question has remained alive after the fall of the dictatorship. This article draws on wider research into Maoism in Portugal between 1964 and 1974, from the creation of the first "pro-Chinese" organization to the fall of the regime. In addition to consulting written sources (the press, documents produced by militant groups, and material from the PIDE/DCS archive), this research also involved carrying out fifty interviews. They will be considered here in order to demonstrate how the "issue of conduct" lingered on in time and how it can help to establish a link between torture, silence, and memory.

These fifty interviews were conducted with former Maoist militants in the final years of Estado Novo. Most of the interviews lasted between two and five hours. They were then transcribed, corrected by the interviewees, and returned to be used as a source. It is important to emphasize that the aim of the research was to understand organizational dynamics and the social background and ideological features of a certain political area (Maoism) at a specific time (the final decade of the Portuguese dictatorship). Each interview, therefore, took as its reference point a specific timeline and a varied set of questions associated with the political sphere. Thus, the experience of imprisonment was only one of a number of topics that were addressed. Seventeen of the fifty individuals interviewed had been prisoners and had suffered some degree of police violence. ${ }^{11}$ In the remaining cases, matters relating to prison and torture were not described as

\footnotetext{
${ }^{10}$ A memoir by Pinto de Sá, published in 2006, led to one of the few public debates on the subject. The book is a compilation of justificatory texts written by the author and produced shortly after the revolution. Comments in newspapers and blogs led to the re-emergence of the debate on "conduct," which focused mainly on the refusal to compare Pinto de Sás collaboration with other types of statements made to the political police. See Pinto de Sá, Conquistadores de almas (Lisbon: Guerra e Paz, 2006). See also the publication, in the Caminhos da memória blog, of a lengthy text analyzing the "issue of conduct." Diana Andringa, "Falar na polícia," Caminhos da memória, accessed June 5, 2012, http://caminhosdamemoria.files.wordpress.com/2009/01/falar_dandringa1.pdf. Diana Andringa, also a former prisoner, argues that-together with personality, type of torture, and organizational precepts - emotional and group ties were also important aspects of prisoners' resistance (and failure to resist).

${ }^{11}$ Approximately twenty former militants who were contacted and invited to take part in the research did not do so (the majority because they failed to respond to the initial contact and others because they were later unable to participate, for various reasons). Three of the four individuals who categorically and expressly refused to give interviews were former prisoners.
} 
firsthand experiences; instead, they emerged in the form of references to family or comrades who had been prisoners or as a threat that always haunted illegal political activity.

The analysis that follows explores the different forms of silence that the issue of conduct raised and continues to raise. First, I analyze the conflict between the "performative" silence of the torture chambers and the fact that "talking" to the PIDE/DGS would later result in the "silencing" of political subjectivity. I then problematize the way in which this conflict creates a tension between what is said and what is silenced, which affects both the narrators and the interviewer. This necessarily leads to a questioning of the role of the interviewer-historian as an active element in the interview and, consequently, in the writing of history.

In general, silence is thought of as omission or absence. In seeking out a practice that is decentered from the history of elites, oral history itself worked from a perspective committed to uncovering silences. Important studies resorted to oral history in order to break the silence surrounding subaltern groups and to "give voice" to those who had no voice audible within the framework in which historiography was usually understood. Paul Thompson, in his seminal work The Voice of the Past, announced that the aim of oral history was to "bring recognition to substantial groups of people who had been ignored."12 This recognition demands the removal of political, social, and historiographical silences. Silence, however, is not always the result of external coercion that erases subjects and communities. Following developments in the field of Holocaust Studies and research into trauma, the notion of silence has become more complex. Attention has been drawn to its mechanisms of production and the possibility that the "management of the unspeakable" (to use an expression of Michael Pollak's) may be more revealing than discourse. ${ }^{13}$

Luisa Passerini explores the ambivalent relationship between silence and memory. Silence may be the result of disturbing episodes that find no social outlet for expression. This was the case with the Nazi massacres of the gypsies (and the Holocaust, up to a certain point), the French war in Algeria, and the war pursued by the United States in Korea. Silence may also have an apparently more "constructive" meaning, when societies decide to suspend deeply painful memories (of civil war, for example) in order to be able to reconstruct common ground. Passerini also draws attention to the importance of nonverbalized memories: traumas and pleasures inscribed in the body, memories of laughter, photographs or gestures, or the custom of holding a minute's silence. All of these examples suggest how memory is not only discursive but also embodied

\footnotetext{
12 Paul Thompson, The Voice of the Past: Oral History (Oxford: Oxford University Press, 1978), 29.

13 Michael Pollak, "La gestion de l'indicible," in Une identité blessée: études de sociologie et d'histoire (Paris: Editions Métailie, 1993), 140-48.
} 
memory. They also indicate how silence is frequently associated with remembrance rather than forgetting. ${ }^{14}$

The expressive nature of silence clearly emerges in the "issue of conduct." In the context of interrogation, this silence took the form of a refusal to answer the inquisitors' questions or later sign the records, which in some cases were forged and presented for signing in circumstances in which all sense of reality had been lost after days without sleep. Various strategies were used to maintain this silence. João Pulido Valente recalled making himself vomit in order to became debilitated but "focussed on the idea of not talking." 15 Aurora Rodrigues remembers using other strategies: making her body absent, building flowers with bread, valuing support from the outside and remembering her friends (referring in particular to José António Ribeiro dos Santos, one of her comrades in the MRPP, who had been shot a few months earlier by the PIDE/DCS), or trying to see her own image. ${ }^{16}$ The objective was always to remain lucid and believe in a capacity to resist that was being put to the test at every moment.

Whenever possible, the PIDE/DGS sought to exploit situations in which prisoners deprived of sleep began to have hallucinations. An understanding of the symptoms could help prisoners bear these torments. Pedro Baptista, a prominent leader of $\mathrm{O}$ Grito do Povo (The Cry of the People), remembers that he knew "by heart and inside out the pathology of torture" and that this helped him to deal with hallucinations involving insects and protest music serenades. ${ }^{17}$ It was also possible to find some encouragement in reading materials. In the intervals between being tortured, Pedro Baptista was allowed to read Don Quixote, which he considered "an essential book for any prisoner contemplating resistance." He considered it essential because "at one point in the book, some prisoners are being sent to the galleys and some of them are ostracized by the others because they were the ones who talked and were convicted as a result, without the police having any evidence." 18 The interviewee was referring to the episode in which

${ }^{14}$ Luisa Passerini, "Memories between silence and oblivion," in Katharine Hodgkin and Susannah Radstone, ed., Contested Pasts: The Politics of Memory (London/New York: Routledge, 2003), 238-54.

15 João Pulido Valente, "João Pulido Valente. 63 anos, médico," testimony in Público, no. 1507, April 22, 1994.

16 Aurora Rodrigues, Gente comum-Uma história na PIDE, compilation, introduction and notes by António Monteiro Cardoso and Paula Godinho (Castro Verde: 100 Luz, 2011). Former MRPP militant Aurora Rodrigues was taken prisoner in 1973 following a student demonstration and endured beatings, blackmail, death threats, and 450 hours of sleep torture. The book is a detailed report of her experiences in jail, although her story remained underground until the book was published. Denying individuals control over their image was one of the first acts of torture to be implemented. Shaving beards, cutting hair, confiscating personal items, refusing personal hygiene routines, and banning mirrors were some of the methods used to break individuals.

17 O Grito do Povo (The Cry of the People) emerged publicly at the end of 1971. In 1973 it merged with 0 Comunista (The Communist), active mainly in European emigrant circles, giving rise to the Organização Comunista Marxista-Leninista Portuguesa, OCMLP (Portuguese Communist Marxist-Leninist Organization-OCMLP).

18 Pedro Baptista, interview by author, audio recording, Oporto, January 16, 2008, interview in author's possession. 
Don Quixote meets some condemned galley slaves on his travels, whom he liberates and who then pelt him with stones as a reward, and asks them why they are being punished. One of them is unable to answer, and a guard explains to Don Quixote that the prisoner was convicted as a cattle thief after making a confession. His confession earns him the scorn of the other prisoners, the guard telling the story, and the wandering knight himself. ${ }^{19}$ The excerpt is effectively an example of moral condemnation of confession, but of particular note is the subtle shift made by Baptista, reading the excerpt in terms of the dilemma facing prisoners in the cells at the PIDE/DGS headquarters. In this reinterpretation, there are those who resist and those who are unable to resist, but protecting other people and the organization is just as important as protecting oneself, if not more so.

Silence before the torturer has a clearly "performative" dimension: It is the act through which prisoners confront repressive attacks and affirm their militant identity. This "affirmative" silence in the face of the PIDE/DGS is the opposite of the "negative" silence that is the result and objective of torture, even if this is not explicitly admitted by the perpetrators. As Jean-Paul Sartre emphasizes, torture "aims to convince us of our impotence." ${ }^{20}$ In fact, torture is not merely a means of extracting information. It seeks, above all, to silence its victims and the groups to which they belong. ${ }^{21}$ As part of his pioneering research into the clinical consequences of the PIDE/DGS interrogations, the psychiatrist Afonso Albuquerque emphasized that rather than simply making prisoners talk, the police were interested in stripping them of their identity and silencing them by means of torture. ${ }^{22}$ Among its other objectives, torture produced silence as well as speech: In addition to providing evidence that could be used in court and facilitating the persecution of comrades, "talking" to the PIDE/DGS also led to the erasure of political subjectivity. The case of Francisco Martins Rodrigues, the leading Portuguese Maoist theorist in the period, is illustrative of this.

Within the context of the Sino-Soviet split, Francisco Martins Rodrigues was expelled from the PCP in December 1963 and a few months later founded the Frente de Acção Popular (Popular Action Front-FAP) and the Comite MarxistaLeninista Português (Portuguese Marxist-Leninist Committee-CMLP). Exiled in Paris, he decided to return to Portugal clandestinely in 1965, together with Rui

\footnotetext{
19 Miguel de Cervantes, The Adventures of Don Quixote, trans. J. M. Cohen (Harmonsworth: Penguin Books, 1975), 172-3.

20 Jean-Paul Sartre, "A Victory," in Henri Alleg, ed., The Question (Lincoln: University of Nebraska, 2006). Sartre's text was published in L'Express on March 7, 1958, and had been written for La question. In this book, Henri Alleg recounts his experience of torture at the hands of the French army in Algeria and how he managed to resist after being given a "truth serum." The text by Sartre would later serve as the preface to almost all editions of the book.

21 See Françoise Sironi, Bourreaux et victimes. Psychologie de la torture (Paris: Odile Jacob, 1999); Françoise Sironi and Raphaëlle Branche, "Torture and the Borders of Humanity," International Social Science Journal 54, no. 174 (2002): 539-48.

22 Albuquerque, Stress.
} 
d'Espiney and João Pulido Valente, the other members of the organization's secretariat. The PIDE/DGS began arresting some of its members, including João Pulido Valente, who had been named by a PIDE/DGS informer inside FAP/CMLP. In a "revolutionary trial" held on November 26, 1965, near Lisbon, the leadership of CMLP decided to execute the informer. The remaining members of the CMLP secretariat were captured by the PIDE/DGS early in 1966. They were submitted to intensive torture sessions and confirmed some names to the police.

Francisco Martins Rodrigues remembered that the PIDE/DGS falsified the records, adding a set of papers to the case file so that in court the entire organization was disclosed in the words of its leader. His conclusion is significant: "the essential thing was that they had managed to extract information and reduce a guy to what they wanted: from then on, that man would be done for." 23 Being "done for" not only meant that he would be despised by his comrades for not resisting assault by the police but, in the final analysis, also meant being aware of the fact that he had been the victim of a process of political disempowerment. Martins Rodrigues continued:

I knew of, maybe not hundreds but certainly dozens, of prisoners from the party who had made statements and the feelings were always the same: I'm nothing now, I'm not a communist any more, I've ruined my life. . . . You were destroyed by it. In fact, later on many of them were allowed back into the party, but there was always that fear of not knowing how they would behave if they had to face the PIDE again. The fact is that a great many of the prisoners who were tortured made statements. Of course the Party had an interest in militants not talking. Chico Miguel was a great believer in this and he was the record-holder, he went days on end without sleep. I'd already read up on it and we'd talked about it in meetings, but experiencing it first hand was different. ${ }^{24}$

This excerpt from Francisco Martins Rodrigues is interesting in several ways. First, it describes an episode that took place when he was already a CMLP militant but refers back to his experiences in the PCP. He had received his political and ideological education from the PCP and had for many years been a militant and a leader of "the Party," as he calls it, using the exclusive and emotive term that militants still use today. However, the continuity he establishes between the PCP model for behaving in police custody and that of the emerging far left is also evident. ${ }^{25}$ Hence his reference, in terms of defining the rule of never

\footnotetext{
23 Francisco Martins Rodrigues, interview by author, audio recording, Lisbon, January 29, 2008, interview in author's possession.

24 Martins Rodrigues interview.

25 Martins Rodrigues interview. Martins Rodrigues stated that executing informers was an act that clearly marked a break with the "gentleness" with which the PCP had treated similar cases.
} 
making statements and observing the "issue of conduct," to communists he had known (such as Chico Miguel). In addition, this excerpt also makes it very clear that "talking" not only put the party at risk but also attacked the core subjectivity of the communist militant: People were "destroyed," their lives "ruined," and they lived with the "fear" that, if reintegrated into the group, their behavior might once again prove unacceptable. In other words, torture not only attacked the body but also the identity of the militant, and it was through the body itself that the task of defending a political option that was also a life choice was played out. The last sentence in this excerpt from Martins Rodrigues points very clearly to the crux of this difficult truth: It was possible to read and talk about the subject, "but experiencing it first hand was different." A huge gulf separated a besieged body and a handbook of procedures.

This gulf is powerfully described in a self-critique, which another prisoner attempted to send outside:

I wanted to fight using the weapons I had, and to fight on even after I realized, when my body failed me and I lost my ability to think clearly, that I had little strength and I was weak and frail, and that I could only have resisted successfully if my commitment to the revolutionary project had been greater, fuller and more intensive and my technical, physical and ideological preparation complete, fully communist in my body as I aimed to be in my mind. ${ }^{26}$

The solution to the problem, therefore, lay in building up a militant body that could conquer pain by means of a strong ideological consciousness. It is important to emphasize that the body here is understood not only as something that preserves or discards a condition (in this case, the communist condition). This condition is not fixed but a process to which the body is not unconnected: "fully communist in my body as I aimed to be in my mind." The body, in this sense, is not simply flesh but also agency, a space that maintains its ability to make choices even under the most adverse circumstances. The body and its capacity to resist are seen as an effective part of the militant condition and, to a certain extent, the thing which completes and consolidates it. The word "full," which also appears in statements in the trials of militants, discloses that their failure to comply with orders to say nothing to the police had deprived them of the status of "full communist militant." 27

Having "talked" had concrete effects. Francisco Martins Rodrigues, although still recognized as the main theorist of the movement, explained that he did not encourage contact with groups "on the outside" while in

\footnotetext{
${ }^{26}$ Record \#PC 679/68, NT 6007, PIDE/DGS Files, Torre de Tombo National Archive, Lisbon, Portugal.

27 Untitled document, undated, Defesa de Rui d’Espiney, Archives of the Centro de Documentação 25 de Abril; Francisco Martins Rodrigues, Os anos do silêncio (Lisbon: Dinossauro/Abrente, 2008), 79.
} 
prison, as he had already begun a process of self-limitation as a result of having "talked."28 Recovering "full communist militant" status, therefore, required a process of ideological "reconstruction" that began in prison, and which is illustrated in the following excerpt. The interviewee, Rita Gonçalves, had just finished talking about how she had been tortured. She had been describing how the PIDE/DGS presented a disfigured man to her (whom she only later realized was her companion of the time) and how she had managed to continue to bear the torture. Then she began to talk about the atmosphere among PCP prisoners in the jail, explaining that she had supported a peasant woman, Faustina, as the spokeperson for the group. Momentarily, the roles are reversed, and it is the interviewee who asks about the "issue of conduct":

RG: Have you heard about a question of conduct?

MC: Yes.

RG: Well, the issue of conduct in police custody is a very important question, very serious. But Faustina was tortured and she didn't talk. You couldn't even say "Ah, but she talked..."

MC: Was this issue of conduct always present?

RG: It wasn't mentioned but it was always there, under the surface. There was one PCP prisoner who was tortured a lot and she talked. She always offered to do things that involved a certain amount of risk. One day the PCP prisoners needed to contact the other group [of prisoners], it was necessary sometimes, and she was caught handing over a paper. She was punished for six months: no visitors, nothing allowed from her family, no this, no that. ... On the other hand the PCP prisoners protected another person they considered "more important," I don't know whether it was because she was the wife of one of the leaders ... and she wasn't allowed to take any risks. I didn't agree with that kind of procedure, although I did think it was very important not to talk to the police. ${ }^{29}$

Although it had not been mentioned explicitly, we had already been talking generally about the "issue of conduct." However, the interviewee thought it necessary to explain it, in order to emphasize its importance. She then revealed how "conduct" was a kind of phantom device - "it wasn't mentioned but it was always there, under the surface" - that functioned as a kind of criteria for (de)classifying prisoners and established the dynamics of blame and exoneration. The interviewee did not contest this classification scheme but rather the

\footnotetext{
28 Martins Rodrigues interview.

${ }^{29}$ Rita Gonçalves, interview by author, audio recording, Lisbon, January 17, 2008, interview in author's possession.
} 
way in which other influences interfered in the militants' characterization. The different levels of risk to which the two prisoners were exposed - one "tortured a lot" and "another person . . . considered "more important" was not allowed to take any risks - enables her to delineate a leftist critique of the PCP, typical of the Maoist camp. In this critique, the egalitarian impulse should erase other political criteria. Therefore, the existence of class and status divisions among prisoners is made explicit and censured by the interviewee, while she also suggested, with some disdain, that the importance of the favored prisoner was due mainly to her marital status.

In Peniche, the prison where convicted male prisoners were held, the "issue of conduct" emerged in the debate on proletarianization. ${ }^{30}$ Rui Teives Henriques, one of the interviewees, clearly makes the connection between the two:

There was a debate about whether we should become proletarianized or not after we were released. In my view, this had a lot to do with the fact that the behavior of a great many of the prisoners in this group whilst they were in jail had not been what was demanded of them by the organization and so they would have to undergo some form of rehabilitation. For some - I remember Francisco Martins Rodrigues supported this - this rehabilitation was to include a process of proletarianization, with people actually living as workers. No longer "petty bourgeois intellectuals," to use the language of the time. In this collective, the person fundamentally opposed to this was João Pulido Valente. He thought that, on the one hand, it would be difficult for people from an academic background to fit into this environment without looking odd and giving themselves away, and also that if there was a revolution it would be more useful for people to stick to their more advanced technical or scientific occupations, so to speak. Doctors should remain doctors, engineers should remain engineers and so on. ${ }^{31}$

Other interviewees spoke of the markedly workerist atmosphere of the ideological discussions in jail but did not relate this to the "issue of conduct." This may be seen as the result of the difficulty, even today, in approaching the "issue of conduct" and the more general subject of torture. In fact, the former prisoners who spoke about this often did so in an indirect or stiff manner, using expressions such as "I'd already read up on it but experiencing it first hand was different" or simply providing information about the types of torture they had

\footnotetext{
30 In the Maoist camp, "proletarianization" extended beyond the scope of "reconstruction" within a prison context. Many politicized young people, mostly students, embarked on a path of downward social mobility with the aim of thinking, living, and acting like the proletariat. The situation in France was studied in detail by Marnix Dressen. See De l'amphi à l'établi. Les étudiants maoïstes à l'usine (1967-1989) (Paris: Belin, 2000).

${ }^{31}$ Rui Teives Henriques, interview by author, audio recording, Lisbon, January 3, 2008, interview in author's possession.
} 
experienced and the number of days it had lasted. Some even declared these subjects taboo as a condition of taking part in the conversation, stipulating a need for personal privacy that should not be violated. ${ }^{32}$

We are, therefore, faced with two kinds of silence that may be considered complementary. First, there was a reaction against naming the horrors experienced in the torture chambers. It should be borne in mind that this difficulty is not unconnected to the fact that pain resists linguistic objectification. As Elaine Scarry emphasizes, torture unmakes agency and reduces the subject to the experience of pain itself. While shrinking the universe to the immediate vicinity of the self, it also erases language: Even when torturers do not permanently eliminate voices by mutilation or assassination, they domesticate them in order to break down the structures of meaning. ${ }^{33}$

Second, there is the presentday muteness of those who were in the past unable to keep the "golden rule" of not talking to the police. The fact that they were not able to equip their body with indestructible armor means that even today it is difficult to address this question since, in the final analysis, it was not only a matter of defending their identity as militants or the integrity of the organization. A confession may also have put other comrades at risk or even led to their imprisonment. The fear that accompanied clandestine political work, therefore, had a collective dimension, based on the need to protect others. As one interviewee said, in a situation in which prison was a constant threat, "the fear is always there. ... The fear of being taken prisoner again wasn't something that scared me that much. It was the fear that I could take other people with me that worried me."34

In this respect, it is important to bear in mind that silence in organizations such as these, which had a proto-Leninist culture and were dedicated to political struggle in a context in which it was forbidden, was not simply a mechanism to protect the group if any militant was arrested. It was based on

\footnotetext{
32 In her study of female guerrillas under the military dictatorship in Brazil, Elisabeth F. Xavier Ferreira also noted the "problematic" nature of approaching experiences of torture and references to "improper" conduct under interrogation. "Oral History and the Social Identity of Brazilian Women under Military Rule," Oral History Review 24, no. 2 (1997): 1-34. Recently, in her article on the persistence of silence in the dictatorships of Argentina and Spain (focused on Catalonia), Laura Benadiba mentioned a former prisoner who agreed to participate in the project "without fear or shame" because, "even though I was busted and tortured, I never gave away any name." Thus, noted Benadiba, not even once "did he specify the kind of torture he had been subjected to." "The Persistence of Silence after Dictatorships," Oral History Review 39, no. 2 (2012): 292.

${ }^{33}$ Elaine Scarry, The Body in Pain: The Making and Unmaking of the World (Oxford: Oxford University Press, 1985), 4-5. Hence certain healing strategies have been developed on the basis of the capacity to recount experiences. This is the case with the "testimony method" created by psychiatrists Inger Agger and Soren Buus Jensen, working with female Chilean refugees in Denmark. See Inger Agger and Soren Buus Jensen, Trauma and Healing under State Terrorism (London: Zed Books, 1996). On torture and silence, see also Elizabeth Stanley, "Torture, Silence and Recognition," Current Issues in Criminal Justice 16, no. 1 (2004): 5-25.

${ }^{34}$ Dúlia Rebocho, interview by author, audio recording, Queluz, November 13, 2007, interview in author's possession.
} 
a "culture of clandestinity" in which no one knew, and no one tried to find out, any names, addresses, or facts that would aid repression. ${ }^{35}$ In fact, few of the interviewees revealed that they had a full and detailed picture of the real dimensions of their organization: its components, spheres of influence, or the internal history that had an impact on the theoretical and organizational development of each group.

\section{The Conflict between Archive and Testimony}

My research involved trawling at length through the archives of the PIDE/DGS. This material is undoubtedly valuable, and without it the contemporary history of Portugal in recent decades would be lacking. However, it is essential to bear in mind that the documentation it contains is not a mirror, even a shattered mirror, of the past. First of all, it must be recognized that the police did not always have detailed information on the organizations they were pursuing and the actions of militants. Their knowledge of the far left groups that began to proliferate in the 1970s was often scant and frequently misleading. While in some cases the gaps were obvious to anyone familiar with the subject, in other cases, it was contact with former activists that led me to recognize certain errors, gaps, and misinterpretations. ${ }^{36}$

It is also essential to bear in mind the context in which these documents were produced: They are, as a rule, materials used to instigate legal proceedings, and they include records with statements made by prisoners. A large number of these confessions were obtained under torture, even though the records do not make this clear. In addition, it is not easy to determine whether the dates or signatures in these documents are forged. In all of them, the dry, bureaucratic language does not disclose the methods of torture used by the PIDE/DGS. Viewed nowadays, the data they contain are an invaluable source in terms of understanding both the repressive apparatus and the opposition to the dictatorship. Yet these documents can also be seen by those who were persecuted as proof that they had "talked." Many are more or less reconciled to this, and the emphasis now lies in the importance of having access to the documents in order to understand the past and repression. However, for others, their relationship to the archive is problematic (confronting them with a time that they do not want

\footnotetext{
35 On the communist culture of clandestinity, see José Pacheco Pereira, A Sombra. Estudo sobre a clandestinidade comunista (Lisbon: Gradiva, 1993).

${ }^{36}$ Comparing the dispute surrounding the opening up of archives in Brazil and Argentina, Ludmila da Silva Catela, while acknowledging the importance of declassifying documents related to political repression, also highlighted the paradox of basing the politics of truth and justice on material that "emerged out of secrecy and concealment and was very often 'assembled' from lies, informer's accounts and invention, to define the other as the enemy." See "Do segredo à verdade . . . processos sociais e políticos na abertura dos arquivos da repressão no Brasil e na Argentina," in Cecília MacDowell Santos, Edson Telles, and Janaína de Almeida Teles, ed., Desarquivando a ditadura. Memória e justiça no Brasil, volume 2 (São Paulo: Editora Hucitec, 2009 ), 448.
} 
to remember), and there have been various cases of resistance to consulting their documents. The past is, therefore, revealed as a troubling past that can still haunt the present.

During the course of my research, an unusual form of evidence appeared of this presence of the past in the present. A former prisoner told me about his exemplary conduct in custody, explaining that a deep moral conviction had prevented him from talking during long days of sleep torture. Members who were active at the time in the same political group corroborated this version and repeated some of the narrative content of the interview. However, the files consulted in the PIDE/DGS archive clearly indicate the opposite, showing some degree of concession. What would seem to be important here is, obviously, not to instigate any kind of new legal proceedings that would compare archives and testimonies, weigh up the "aggravating" and "mitigating" circumstances, and then deliver a verdict on "the truth." Regardless of the matter of understanding the reasons that justify this former prisoner's account, this episode is illustrative of how the past remains alive and significant in the present. The "issue of conduct" is, therefore, revealed as the element that disturbs the image, which subjects construct for themselves and for others. Following a logic of "composure," memories that evoke this tend to be repressed, revised, or silenced, so that, in this case, the experience matches the required standards and desired self-image. ${ }^{37}$

\section{Silences in the Interviews}

Understanding what is said or silenced is also a subject that has been addressed by oral historians, who have drawn attention to the need to adopt a hermeneutics of silence, reticence, and narrative pace. ${ }^{38} \mathrm{It}$ is important to note that in my research the "issue of conduct" was not initially envisaged as a central subject of the interviews, which dealt with different aspects of militancy in this period.

37 On the concept of "composure," see Alistair Thomson, "Anzac: Putting Popular Memory Theory into Practice in Australia," Oral History 18, no. 1 (1990): 25-31.

38 The classic works by Luisa Passerini and Alessandro Portelli are, to a great extent, approaches to the spoken and unspoken, exploring what is silenced by memory or the discrepancy between reality and remembrance. See, for example, Passerini, "Work, Ideology and Consensus under Italian Fascism," History Workshop Journal 8, no. 1 (1979): 82-108; Passerini, Fascism in Popular Memory: The Cultural Experience of the Turin Working Class (Cambridge: Cambridge University Press, 1984); Portelli, The Death of Luigi Trastulli, and Other Stories: Form and Meaning in Oral History (Albany: State University of New York Press, 1991); Portelli, The Order Has Been Carried Out: History, Memory and Meaning of a Nazi Massacre in Rome (Basingstoke: Palgrave, 2003). From another perspective, see Michael Pollak, "Mémoire, oubli, silence," in Une identité blessée: études de sociologie et d’histoire (Paris: Editions Métailie, 1993). On reticence, see Lenore Layman, "Reticence in Oral History Interviews," Oral History Review 36, no. 2 (2009): 207-30. On the narrative pace, see Alessandro Portelli, "What Makes Oral History Different," in Robert Perks and Alistair Thomson, eds., The Oral History Reader (London/New York: Routledge, 2006), 32-42. 
The interviewees were asked to give an autobiographical narrative based on the timeframe of the 1960s and 1970s, covering politics in general. ${ }^{39}$ They knew they were speaking to a wider audience since their words would be used in academic research that was due to be published. Most of them were perfectly aware that their stories were important as part of the history of the struggle against the dictatorship. There was also the fact that some were, to a certain extent, in the public eye, which made them manage what was said and not said with greater caution. Therefore, from the outset it was stipulated that the recorded interview would only be the first step in constructing the source. After transcription, there would be a point at which the interviewees would have the opportunity to correct, delete, or add to the transcript.

Sharing control of the transition from oral to written source with the interviewee meant that elements considered problematic were removed; names were blanked out; interjections, pauses, and stammering omitted; and some of the spontaneity of the conversation was lost. However, this method also had important advantages. First, it allowed information to be corrected, which was important for the type of oral history produced here, involving the reconstruction of phenomena for which there are few written sources. Second, it enabled narrators to talk more freely, knowing that their words would not necessarily represent the definitive version. Third, from the point of view of the interviewees, the correction process meant that their words would be recorded in writing in terms with which they could identify. Since the majority came from intellectual backgrounds or were accustomed to communicating in writing, fluent and accurate expression was not neglected. For all these reasons, sharing control over the construction of the source with the interviewee-a form of "shared authority," to use Michael Frisch's expression - was fundamental in this case to establishing the essential relationship of trust. ${ }^{40}$

There is, however, another reason for the lingering periods of silence in the interviews regarding the "issue of conduct." I did not, in fact, feel I had the right to touch directly on such a sensitive area. I had an open-ended script for each interview, which included the subject of torture and prison experiences for

\footnotetext{
39 It is recognized that one of the potential uses of oral sources is precisely to show how the boundaries between public and private can be malleable. Although my research focused on political dynamics, the narratives frequently incorporated references to intimate, private, and family matters. Many of the interviewees, for example, stressed the importance of the family or the community in the early days of their growing politicization. It is also important to emphasize that in small groups, such as the ones I studied, whose members almost always came from a particular social background, had a strong sense of identity, and were explicitly engaged in challenging the state and the authorities, the distinction between public and private is sometimes genuinely blurred. This is very evident in one aspect that emerges particularly clearly in the interviews (contrary to the written documents, where it is imperceptible), namely the tendency, in the lives of militants, for circles dedicated to political comradeship and those dedicated to ordinary friendships to coincide.

40 Michael Frisch, A Shared Authority: Essays on the Craft and Meaning of Oral and Public History (Albany: State University of New York Press, 1990).
} 
interviewees who had been prisoners. However, I never openly asked about that question of conduct if I felt there was an unwillingness on the part of the interviewee to pursue the matter. I only got a clear sense of my own reticence when rereading the transcripts and identifying questions that circled around conduct and approaches to the subject of torture and prison that did not mention it, as was the case with Rita Gonçalves when, at a certain point, the interviewee herself drew attention to it, thus revealing its centrality.

I sensed that the empathy established between interviewer and interviewee might have been threatened. This fear of leading the interviewee into difficult ground reflects what Mark Klempner has termed the "principle of reciprocity," namely establishing empathy as the shared and necessary ethical basis for interviewing those who have suffered painful experiences. ${ }^{41}$ However, this reticence also reflected my own internalization of the still problematic nature of the subject. This leads to a consideration of how the interviewer is an active element in the interview and how this is much more than a one-sided process of collecting information and memories. According to Alessandro Portelli, the relationship between interviewer and interviewee is one of a number of features that make "oral history different" (together with orality, narrative form, subjectivity, and the "different credibility" of memory). Oral history documents are the result of a relationship in which both parties share a common project, although not from the same level or perspective. ${ }^{42}$

From an over-schematic perspective, it may be said that the interview is a process in which two subjectivities converge: that of the interviewer, who wants to know things, and that of the interviewee, who agrees to tell them. We know, however, that what is told changes depending on the interviewer. ${ }^{43}$ We also know that interviews can take complex forms: Both the interviewer and the interviewee have their own agendas, expectations, motives, and mental outlook. The interview, therefore, has an unavoidably interactive dimension which, according to Valerie Yow, has become more explicit since the end of the 1980s. ${ }^{44}$ This means taking into account the role of the historian as an active

${ }^{41}$ For a consideration of the attitude of the narrator with regard to interviewees who have undergone painful experiences (in this case, the traumatic experiences of Holocaust survivors), see Mark Klempner, “Navigating Life Review: Interviews with Survivors of Trauma," Oral History Review 27, no. 2 (2000): 67-83. For a view on the relationship between trauma and life stories, see Kim Lacy Rogers, Selma Leydesdorff, and Graham Dawson, ed., Trauma: Life Stories of Survivors (New Brunswick, New Jersey: Transaction Publishers, 2004). For an analysis of the subject of trauma in oral history studies, see Robert Reynolds, "Trauma and the Relational Dynamics of Life-History Interviewing," Australian Historical Studies 43, no. 1 (2012): 78-88.

42 Portelli, "What Makes Oral History Different."

43 Alessandro Portelli, "Conversations with the Panther: The Italian Student movement of 1990," in The Battle of Valle Giulia. Oral History and the Art of Dialogue (Wisconsin: Wisconsin University Press, 1997), $249-72$.

${ }^{44}$ Valerie Yow analyses how the interviewer affects, and is affected by, the interview. "'Do I Like Them Too Much?': Effects of the Oral History Interview on the Interviewer and Vice-Versa," Oral History Review 24, no. 1 (1997): 55-79. 
agent in the process of constructing oral sources and, subsequently, in the writing of history that draws on these sources.

In my case, the fact that I was aiming to produce a history of a certain type of opposition to the dictatorship, without having experienced this myself, influenced the discourse of the narrators. I was frequently aware of the generation gap, which could lead to a certain condescension or the omission of details that required a tacit understanding of the 1960s and 1970s "spirit of the time." 45 Yet, on the other hand, it also led to openings based on the idea of leaving a legacy or the desire to see their story incorporated into the wider history of radical opposition to the dictatorship. In addition, I felt a general empathy towards those who had agreed to share their experiences with me, which explains a certain reserve towards specifically approaching the "issue of conduct," if interviewees had not taken the first step towards making the subject approachable. It was as if I did not have the right to prolong what the dictatorship had produced.

\section{Conclusion}

This analysis of the behavior of militants in the face of torture illustrates how historical time has cycles that do not coincide with the cycles of personal and social memory. Viewed superficially, it might seem that the fall of the dictatorship in Portugal would have rendered the "issue of conduct" obsolete. Instead, it remained active in the years that followed and is still a sensitive subject today. The nature of the experience of torture, which is difficult to overcome, and the extreme demands of the general rule of never talking to the police meant that the question remained open over time. To a certain extent, persecution, torture, and imprisonment did not end with April 25, 1974, and they are still reflected today in the bodies, speech, and silences of former prisoners.

Exploring the "issue of conduct" also allows for a complex approach to the notion of silence. This complexity was shaped into a conflict at the time, one which pitted loud affirmation of the heroism demanded in the torture chambers

\footnotetext{
${ }^{45}$ The specific nature of the "long sixties" (to use an expression based on Fredric Jameson's periodization) gave birth to a growing academic field. On the sixties Weltanschauung, see Fredric Jameson, "Periodizing the 60s," Social Text 9-10 (1984): 178-209; George Katsiaficas, The Imagination of the New Left: A Global Analysis of 1968 (Boston, Massachusetts: South End Press, 1987); Arthur Marwick, The Sixties: Cultural Revolution in Britain, France, Italy, and the United States, c. 1958 - c. 1974 (New York: Oxford University Press, 1998); Julie Stephens, Anti-Disciplinary Protest: Sixties Radicalism and Post-Modernism (Cambridge: Cambridge University Press, 1998); Jeremi Suri, Power and Protest: Global Revolution and the Rise of Détente (Cambridge: Harvard University Press, 2003); Gerd-Rainer Horn, The Spirit of '68: Rebellion in Western Europe and North America, 1956-1976 (Oxford: Oxford University Press, 2007); Martin Klimke and Joachim Scharloth, ed., 1968 in Europe: A History of Protest and Activism, 1956-1977 (New York: Palgrave MacMillan, 2008). In 2008, a journal appeared dedicated to the study of the period: The Sixties. A Journal of History, Politics and Culture. For an analysis focused on the Portuguese case, see Rui Bebiano, O poder da imaginação: Juventude, rebeldia e resistência nos anos 60 (Coimbra: Angelus Novus, 2003).
} 
(to silence information) against any breakdown before the torturer and subsequent confession (leading to the erasure of the militant identity). This silencing of identity led to processes of ideological "reconstruction" but also to difficulties, even today, in dealing with memories of behavior under torture. The way in which this past endures in the present is revealed in terms of what was said and unsaid in the interviews. Taking into account the hesitations, deviations, and silences, the "issue of conduct" has maintained an unusual presence in the present day.

Miguel Cardina is a historian and a researcher at the Centre for Social Studies of the University of Coimbra and a postdoctoral researcher at the Institute of Contemporary History, New University of Lisbon. His works focus on the dynamics between history, memory, and oral testimony, and on the analysis of political radicalism during the 1960s and 1970s. E-mail: miguelcardina@gmail.com. 